\title{
THE USE OF HETEROGENOUS (MURINE) HYPERIMMUNE ANTISERA IN B-SA IMMUNOHISTOCHEMICAL EVIDENCE OF ENCEPHALITOZOON CUNICULI ANTIGENS IN RABBITS
}

\author{
M. ŠTEFKOVIČ, J. ROSOCHA, M. HALÁNOVÁ, M. HORVÁTH \\ University of Veterinary Medicine, Košice, \\ Slovak Republic
}

Received March 24, 1997

Accepted June 17, 1997

\begin{abstract}
Śtefkovič M., J. Rosocha, M. Halánová, M. Horváth: The Use of Heterogenous (Murine) Hyperimmune Antisera in B-SA Immunohistochemical Evidence of Encephalitozoon cuniculi Antigens in Rabbits. Acta vet. Brno 1997, 66: 95-99.

Immunocompetent mice of the $\mathrm{C}_{57} \mathrm{BL}_{6}$ colony were experimentally infected with Encephalitozoon cuniculi to produce hyperimmune antisera. The mice were six times immunized intraperitoneally with doses of $6 \times 10^{6}$ agent spores in a single $0.5 \mathrm{ml}$ volume of PBS at three-day intervals. An indirect immunofluorescence of antibodies was performed for the detection of immunological responses to the infection. The IFAT IgG titres obtained were from 1: 1,024 up to 1: 4,096 on the 19th day after the first inoculation. Clinical signs and pathological changes in the mice were observed.

Histological sections of the liver, kidneys, spleen, brain, and lymph nodes from the rabbits infected naturally and experimentally with $E$. cuniculi were examined immunohistochemically. The spores were demonstrated by means of the Biotin-Streptavidin Amplified peroxidase detection system using heterogenous murine hyperimmune antisera. Numerous microsporidia were found in the inflammatory granulomas of the rabbits examined. Spores were mostly localized inside the macrophages within parasitophorus vacuoles.

B-SA immunohistochemistry using biotinylated heterogenous murine anti-Encephalitozoon cuniculi IgG, described in this work, appears to be a suitable method of confirmation intravital diagnosis of the infection by detection of the parasite antigens in tissues.
\end{abstract}

Microsporidial infections, Encephalitozoon cuniculi, hyperimmunization, immunohistochemistry, mice, rabbits

Microsporidia are strict, intracellular, spore-forming protozoa that appear to be ubiquitous in nature, infecting a variety of cell types in a broad range of both invertebrate and vertebrate hosts (B ry an 1995). Encephalitozoon cuniculi, Levaditi, Nicolau and Schoen, 1923 (syn. Nosema cuniculi) is a relatively frequent mammalian parasite occurring in colonies of laboratory animals (rabbits, mice, rats, guinea pigs, hamsters), and in farmed rabbits. Moreover, encephalitozoonosis has also been observed in several species of carnivores - in dogs (Plowright 1952), farmed blue foxes (Nordstog a et al. 1972) and in the mink (B jerkås 1990). Furthemore, microsporidia are increasingly recognized as causing opportunistic infections in human patients with AIDS (Shadduck 1989; Orenstein 1991).

Immunocompetent hosts infected naturally or experimentally by the microsporidia usually show only a few clinical signs of the disease, yet the microsporidia persist to cause chronic infections that last for the lifetime of the host (Shadduck and Pakes 1971). In contrast, the inoculation of immunodeficient animals, such as athymic mice, resulted in lethal systemic disease after infections (Gannon 1980; Schmidt and Shadduck 1983).

Brain and kidneys are considered as target organs with the typical pathological lesions caused by E. cuniculi. In these organs the microsporidia usually caused the inflammatory 
microgranulomas (Pakes and Gerrity 1994) that can be observed in histological sections. These are commonly being stained in the standard ways of processing, predominantly with Haematoxylin-Eosin (HE), Giemsa stain, and Luxol Blue.

The aim of the study reported here was an immunohistochemical demonstration of the $E$. cuniculi spores in the histological sections from organs of infected rabbits using the specific heterogenous hyperimmune antisera of mouse origin.

\section{Materials and Methods}

In the experiment, eight four-month-old males of an inbred conventional mice colony $\left(\mathrm{C}_{57} \mathrm{BL}_{6}\right)$ were used for producing hyperimmune antisera against $E$. cuniculi. Three groups of 4 mice per standard plastic cage were housed in pathogen-free environment. Mice were offerred mouse diet and water ad libitum. Animals were originally obtained from the laboratory colony (Ing. To mašovičová, Parasitological Institute of the Slovak Academy of Sciences, Košice, Slovak Republic), that proved negative in IFAT test.

Encephalitozoon cuniculi organisms isolated from mice were grown in „E6“ cells of Vero Green Monkey Kidney Culture. The cells were cultivated in modified RPMI 1640 medium with an addition of $5 \%$ foetal calf serum. The spores freshly collected from the culture supernatants according to K o u de la et al. (1993) were used for both animal inoculation and IFAT serological examinations as an antigen.

All mice were immunized intraperitoneally (i.p.) with six inoculations of $6 \times 10^{6} \mathrm{E}$. cuniculi spores in a single $0.5 \mathrm{ml}$ volume of phosphate-buffered saline (PBS) at three-day intervals. The whole dose given to each mouse during hyperimmunization was $3.6 \times 10^{7}$ of the spores. Hyperimmune antisera were obtained from blood collected by decapitation on the 3 rd day after the last injection. Sera were stored frozen at $-20^{\circ} \mathrm{C}$ until used.

The indirect immunofluorescent antibody test in the mice was performed according to Chalupský et al. (1973). The animals whose sera reacted at a dilution of 1: 64 or higher, were considered to be positive (Le v kut et al. 1996).

The commercial swine-anti-mouse conjugates (SwAM/FITC) used in the test were obtained from the SEVAC a.s., Prague, Czech Republic.

Sixty three samples of internal organs (liver 10 , kidneys 27 , spleen 10 , brain 8 , and lymph nodes 8 ) of the 17 rabbits infected naturally (Levkut et al. 1997) and 10 rabbits infected experimentally (Horváth et al. 1996) were examined for demonstration of $E$. cuniculi. The samples were fixed in $10 \%$ neutral formalin and processed by common paraffin technique. The sections of thickness 5-6 $\mu \mathrm{m}$ obtained were stained by Giemsa stain, PAS, HE and Luxol Blue.

Immunohistochemical procedure was performed on undigested paraffin histological sections using our murine hyperimmune antiserum to $E$. cuniculi diluted in ratio $1: 1,000$ in PBS. The slides were incubated at $4{ }^{\circ} \mathrm{C}$ for 18 hours. Afterwards, the sections were incubated with the biotinylated anti-mouse immunoglobulins and finally with peroxidase-labelled streptavidin in PBS (Biogenex, San Ramon, CA, USA). Visualization of the immunological reactions was performed by means of diaminobenzidine (DAB). The sections were finally counter-stained by Mayer's haematoxylin.

\section{Results}

The infected mice developed the first clinical signs after the third inoculation at eight to nine days. First, there were lethargy, dermatitis characterized by hyperkeratosis and crusts followed by hypotrichosis observed in most of the mice. Signs of ascites and facial oedema of different degree appeared five to six days later in some of them (Tab. 1). None of the animals infected died until the end of hyperimmunization on the 19th day.

The examination of mice serum samples collected by decapitation just prior to euthanasia showed high positivity to E. cuniculi. The levels of specific antibodies corresponded to $\operatorname{IgG}$ titres of 1:1,024 up to 1: 4,096 (Tab. 1). Four control animals were serologically negative.

At the mice necropsy, the most important pathological changes were observed in abdominal cavity, peritoneum, and liver. Accumulation of the straw-coloured ascites fluid in the abdominal cavity, peritonitis of different degree (serosa, granulomatosa), and oedematous infiltration of the facial subcutaneous tissue were found in most of the mice (Tab. 1). The presence of granulomatous peritonitis with several greyish foci scattered was detected in mice No. 5 and 7, respectively. Moreover, mouse No. 5 displayed splenomegaly 
Table 1

Results of serological examination, clinical signs and pathological changes in the mice hyperimmunized with $E$. cuniculi

\begin{tabular}{|c|c|c|c|c|c|c|c|c|c|c|}
\hline Mouse & IFAT titer & \multicolumn{4}{|c|}{ Clinical signs } & \multicolumn{5}{|c|}{ Pathological findings } \\
\hline M 1. & $1: 1.024$ & $\mathrm{~L}$ & $\mathrm{D}$ & - & Fo & - & - & $\mathrm{O}$ & & \\
\hline M 2. & $1: 1.024$ & $\mathrm{~L}$ & $\mathrm{D}$ & A & Fo & Af & $\mathrm{P}$ & $\mathrm{O}$ & & \\
\hline M 3. & $1: 4.096$ & $\mathrm{~L}$ & $\mathrm{D}$ & A & - & Af & $\mathrm{P}$ & $\mathrm{O}$ & & \\
\hline M 4. & $1: 1.024$ & $\mathrm{~L}$ & $\mathrm{D}$ & - & - & - & & - & & \\
\hline M 5. & $1: 2.048$ & $\mathrm{~L}$ & $\mathrm{D}$ & A & Fo & Af & $\mathrm{P}^{*}$ & $\mathrm{O}$ & $\mathrm{Sm}$ & $\mathrm{Hm}^{*}$ \\
\hline M 6. & $1: 2.048$ & $\mathrm{~L}$ & - & A & Fo & Af & $\mathrm{P}$ & - & & \\
\hline M 7. & $1: 2.048$ & $\mathrm{~L}$ & $\mathrm{D}$ & A & Fo & Af & P* & $\mathrm{O}$ & & \\
\hline M 8. & $1: 1.024$ & - & $\mathrm{D}$ & - & Fo & - & - & $\mathrm{O}$ & & \\
\hline M9. C & - & & & & & & & & & \\
\hline M 10. C & $1: 16$ & & & & & & & & & \\
\hline M 11. C & - & & & & & & & & & $\mathrm{Hm}$ \\
\hline M 12. C & $1: 8$ & & & & & & & & & \\
\hline
\end{tabular}

Notes:

C - Control animal

Af - Ascites fluid

L - Lethargy

D - Dermatitis

A - Ascites

$P$ - Peritonitis

O - Oedema of facial hypodermic tissue

Fo - Facial oedema

Sm - Splenomegaly

$\mathrm{Hm}$ - Hepatomegaly

* - granuloma lesions

and mild hepatomegaly with several yellowish nodular lesions. It is worth mentioning that none of the mice kidneys was macroscopically changed.

Histologically, peritoneal foci were constituted by inflammatory oedema and cell infiltration with predominance of macrophages and lymphocytes. Facial subcutaneous oedema was filled with inflammatory cell infiltration of similar structure. Microlesions in the liver and some kidneys predominantly showed fibrotization and focal granulomatous inflammation without central necrotization. The granulomas consisted of numerous macrophages, several plasma cells, lymphocytes, and a few eosinophils.

The murine anti-E. cuniculi IgG isolated from the infected mice reacted immunologically with the microsporidial antigens in histological sections. Consequently, spores were visualized immunohistochemically by means of B-SA peroxidase detection system.

Numerous microsporidial organisms were observed in the liver, kidneys, spleen and brain of the examined rabbits. The spores were localized predominantly inside the macrophages and histiocytes within parasitophorus vacuoles (Fig. 1). Some free spores were observed in inflammatory granulomas and also inside the urine space of the kidney bodies (Fig. 2).

\section{Discussion}

Encephalitozoonosis is a well-known microsporidial infection with chronic, usually latent course in immunologically competent mammals.

The immunosuppressive agents influence the development of clinical and pathomorphological changes in serologically positive individuals (B ále n t et al. 1995). An experimental model using $E$. cuniculi-infected $\mathrm{BALB} / \mathrm{c}$ mice demonstrated that the immune system is responsible for preventing of fatal outcome ( $\mathrm{Schmidt}$ and $\mathrm{Sh}$ adduck 1983; 1984). 
The development of acute microsporidiosis with clinical signs and histopathological lesions has been reported in SCID mice after infection with $10^{7}$ E. cuniculi spores in a single dose (H er mánek et al. 1993), while immunocompetent mice (BALB/c) did not show any noticeable signs of the disease. Didier et al. (1994) described that none of the euthymic mice (BALB/c and $\mathrm{C}_{57} \mathrm{BL}_{6}$ ) developed clinical signs of the disease after inoculation with $10^{6}$ causative spores only. The occurrence of clinical illness in the mice in our experiment was probably caused by the much higher total dose of inoculated microsporidia and also by the way in multiple inoculations.

The intravital diagnosis of the disease consists in serological examinations. Less frequently, methods of direct detection of the microsporidial spores are used, e.g. by means of optical brighteners (Vávra et al. 1993). Occasionally, the causative agents are isolated from urine, kidneys, peritoneal fluid. and macrophages.

Post mortem diagnosis particularly consists in demonstration of the pathological lesions caused by microsporidia and in the presence of the agent spores. Although the E. cuniculi spores could be stained with Giemsa, Gram's and with silver impregnation methods, there exist some difficulties of their visualization in histological sections (P a rk et al. 1993).

For detection E. cuniculi antigens in tissues, indirect and direct fluorescent as well as immunohistochemical methods have been performed. Park et al. (1993) used homologous rabbit biotinylated anti-E. cuniculi IgG prepared from one of the 9 spontaneously infected rabbits in avidin-biotin peroxidase complex $(\mathrm{ABC})$ immunohistochemistry. Using immunohistochemical methods, even one or two spores of $E$. cuniculi present in the affected tissue could be detected.

All our examined rabbits had the IFAT IgG titres of 1.024 to 2.048 (Le v kut et al. 1997, Horváth et al. 1996) during their life. To confirm results mentioned above, we examined histological sections taken from the rabbits using indirect (B-SA) immunohistochemistry with heterogenous antisera. The presence of microsporidial spores in the tissues corresponded to the response of rabbit's immune system so that the results of our study have confirmed pathological affecting of the parasite.

\section{Využitie heterogénneho (myšacieho) hyperimúnneho antiséra v B-SA imunohistochemickom dôkaze antigénov Encephalitozoon cuniculi u králikov}

Imunokompetentné myši kmeňa $\mathrm{C}_{57} \mathrm{BL}_{6}$ boli experimentálne infikované mikrosporídiami druhu Encephalitozoon cuniculi, aby vytvorili hyperimúnne antiséra. Myši boli imunizované intraperitoneálne 6-krát $\mathrm{v}$ trojdňových intervaloch dávkami $6 \times 10^{6}$ spór pôvodcu $\mathrm{v}$ jednorázovom objeme $0,5 \mathrm{ml}$ PBS. Imunitná odpoved $\mathrm{k}$ infekcii bola testovaná metódou nepriamej imunofluorescencie protilátok. $\mathrm{Na} 19$. deň od prvej inokulácie boli zistené IFAT IgG titre od 1:1 024 do 1:4 096. U myší boli pozorované jednak klinické príznaky, ako aj patologické zmeny.

Imunohistochemicky boli vyšetrené histologické rezy pečene, obličiek, sleziny, mozgu a lymfatických uzlín, získané z králikov prirodzene aj experimentálne infikovaných mikrosporídiami $E$. cuniculi. Spóry pôvodcu boli detekované pomocou B-SA peroxidázového detekčného systému za použitia myšacích hyperimúnnych antisér. U vyšetrovaných králikov bolo v zápalových granulómoch pozorované množstvo mikrosporídií. Spóry boli najčastejšie lokalizované v makrofágoch vo vnútri parazitoforných vakuol.

V tejto práci popísaná B-SA imunohistochemická reakcia, za použitia biotinylovaných heterogénnych myšacích anti-Encephalitozoon cuniculi IgG, sa ukázala ako vhodná metóda pre potvrdenie intravitálnej diagnózy infekcie detekciou antigénov parazita $\mathrm{v}$ tkanivách. 


\section{Acknowledgements}

We should like to thank Mrs. Maceková for technical assistance. This work was supported by grant No. 1024/94 of the Ministry of Education and Science of the Slovak Republic, that is also gratefully acknowledged.

\section{References}

BÁLENT. P.. KOLODZIEYSKI, L., HIPÍKOVÁ, V. 1995: Encephalitozoonosis - the actual disease in rabbits also in Slovakia. Slov. Vet. J. 20:81-83

BJERKÅS, I. 1990: Brain and spinal cord lesions in encephalitozoonosis in mink. Acta Vet. Scand. 31:423-432

BRYAN, R. T. 1995: Microsporidiosis as an AIDS-Related opportunistic infection. Clin. Infect. Dis. 21:62-65

CHALUPSKÝ, J., VÁVRA. J., BEDRNÍK. P. 1973: Detection of antibodies to Encephalitozoon cuniculi in rabbits by the indirect immunofluorescent antibody test. Folia Parasitol. 20:1-8

DIDIER, E. S., VARNER, P. W., DIDIER, P. J., ALDRAS, A. M., MILLICHAMP, N. J., MURPHEY-CORB, M., BOHM, R.. SHADDUCK. J. A. 1994: Experimental microsporidiosis in immunocompetent and immunodeficient mice and monkeys. Folia Parasitol. 41:1-11

GANNON, J. 1980: The course of infection of Encephalitozoon cuniculi in immunodeficient and immunocompetent mice. Lab. Anim. 14:189-192

HEŘMÁNEK. J., KOUDELA, B., KUČEROVÁ. Z.. DITRICH. O., TRÁVNÍČEK. J. 1993: Prophylactic and therapeutic immune reconstitution of SCID mice infected with Encephalitozoon cuniculi. Folia Parasitol. 40:287-291

HORVÁTH, M., LEVKUT, M., BÁleNT, P., LEVKUTOVÁ, M., HIPIKOVÁ, V., ŠTEFKOVIČ, M., HALÁNOVÁ, M.. HORVÁTHOVÁ, A. 1996: Pathological changes in rabbits infected with Encephalitozoon cuniculi rectally. Helminthol. 33:121-124

KOUDELA, B., VÍTOVEC, J., KUČEROVÁ. Z., DITRICH, O., TRÁVNÍČEK, J. 1993: The severe combined immunodeficient mouse as a model for Encephalitozoon cuniculi microsporidiosis. Folia parasitol. 40:279-286

LEVADITI, C.. NICOLAU, S., SCHOEN. R. 1923: L'agent etiologique de l'encephalite epizootique du lapin (Encephalitozoon cuniculi). Comptes Rendus de l'Academie des Sciences (Paris). 89:984-986

LEVKUT, M., LEŠNÍK, F., BÁLENT, P., ZAJAC, V., KORIM, P., SLÁVIKOVÁ, K. 1997: Bovine leukemia virus-induced clinical signs and morphological changes of encephalitozoonosis in rabbits. Folia Parasitol. in press.

LEVKUT, M., LEVKUTOVÁ, M., HIPIKOVÁ, V., KOLODZIEYSKI, P., BÁLENT, P., BAJOVÁ, V. 1996: Demonstration of antibodies to Encephalitozoon cuniculi in rabbits on some Slovak farms. Helminthol. 33:25-26

NORDSTOGA, K. 1972: Nosematosis in blue foxes. Nord.Vet.Med. 24:21-24

ORENSTEIN, J. M. 1991: Microsporidiosis in the acquired immunodeficiency syndrome. J. Parasitol. 77:843-864

PAKES, S. P., GERRITY, L. W. 1994: Protozoal diseases. III. Microsporidia. In: MINNING, P. J., RIGLER, D. H., NEWCOMBER, C. E. (Eds.): The Biology of the Laboratory Rabbit. Academic Press Inc., San Diego, pp. 215-220

PARK, J. H., OCHIAI, K., ITAKURA, CH. 1993: Direct ABC immunohistochemistry to Encephalitozoon cuniculi. J. Vet. Med. Sci. 55:325-328

PLOWRIGHT, W. 1952: An encephalitis-nephritis syndrome in the dog probably due to congenital encephalitozoon infection. J. Comp. Path. 62:83-92

SCHMIDT, E. C., SHADDUCK, J. A. 1983: Murine encephalitozoonosis model for studying the host-parasite relationship of a chronic infection. Infect. Immun. 40:936-942

SCHMIDT, E. C.. SHADDUCK, J. A. 1984: Mechanisms of resistance to the intracellular protozoon Encephalitozoon cuniculi in mice. J. Immunol. 133:2712-2719

SHADDUCK, J. A. 1989: Human microsporidiosis in AIDS. Rev. Infect. Dis. 11:203-207

SHADDUCK, J. A., PAKES, S. P. 1971: Spontaneous diseases of laboratory animals which interfere with biomedical research. Encephalitozoonosis and Toxoplasmosis. Am. J. Pathol. 64:657-674

VÁVRA, J., NOHÝNKOVÁ, E., MACHALA, L., ŠPÁLA, J. 1993: An extremely rapid method for detection of microsporidia in biopsy materials from AIDS patients. Folia parasitol. 40: 273-274

Address for correspondence:

Dr. Milan Štefkovič

Section of Biology

University of Veterinary Medicine

Komenského 73

04181 Košice

Slovak Republic 


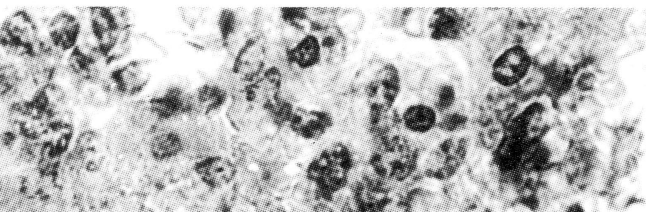

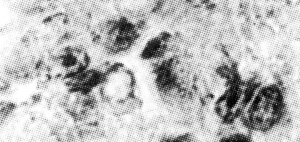

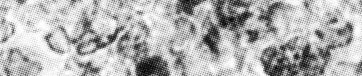

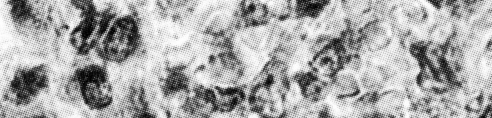
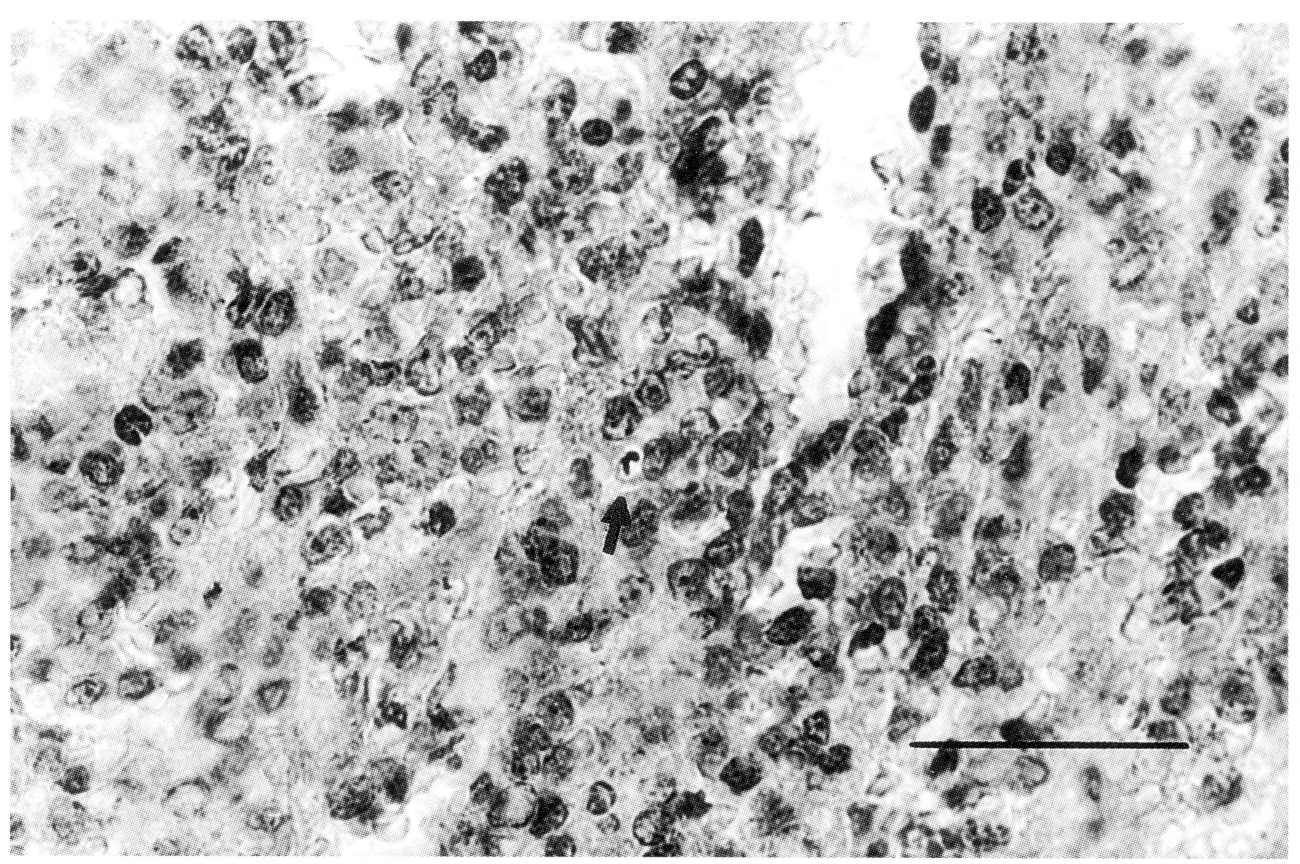

Fig. 1. E. cuniculi spores inside the macrophage in red pulp of spleen within parasitophorus vacuole (arrow) are stained positively. Biotin-Streptavidin Amplified peroxidase immunohistochemistry, x 400 (Levkut et al. 1997). Bar $=50 \mu \mathrm{m}$.

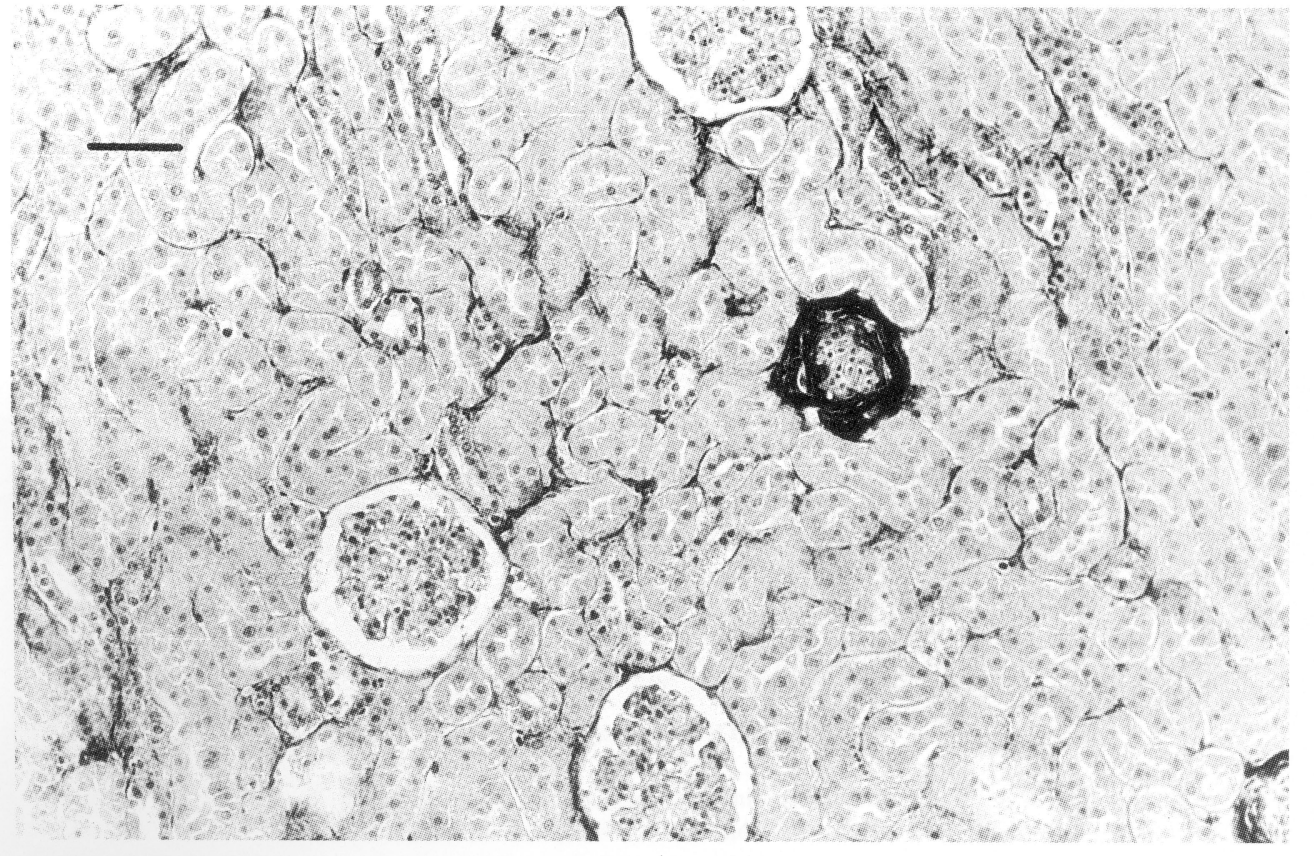

Fig. 2. Numerous microsporidia in the urine space of a renal body of rabbit kidney. B-SA peroxidase immunohistochemistry, x 160 (Horváth et al. 1996). Bar $=50 \mu \mathrm{m}$. 